\title{
A APLICACÃO DOS PRINCÍPIOS DE PROTECÃO DO CONSUMIDOR AO COMÉRCIO ELETRÔNICO NO DIREITO BRASILEIRO $^{2}$
}

\section{CESAR VITERBO MATOS SANTOLIM}

\section{RESUMO:}

A partir de uma visão do Direito como um conjunto de regras, mas também de princípios, o objetivo deste trabalho é o investigar até onde o sistema de proteção ao consumidor, no direito brasileiro, mostra-se adequado às relações jurídicas que compõem o comércio eletrônico.

\footnotetext{
${ }_{2}^{2}$ A Banca Examinadora da Tese de Doutorado foi composta pela Professora Doutora Cláudia Lima Marques, Professora Titular da Universidade Federal do Rio Grande do Sul e Doutora em Direito pela Universidade de Heidelberg Alemanha; pelo Professor Doutor Carlos Alberto Ghersi, Professor da Universidade de Buenos Aires e Doutor em Direito pela Universidad de Buenos Aires; pelo Professor Doutor Jorge Mosset Iturraspe, Professor da Universidad del Litoral - Santa Fé e Doutor pela Universidad de Buenos Aires; pelo Professor Doutor Newton De Lucca, Professor da Universidade de São Paulo e Doutor em Direito pela Universidade de São Paulo; e pelo Professor Doutor Raimundo Feitosa, Professor da Universidade Federal de Pernambuco e Doutor em Direito pela Universidade Autônoma de Madrid. Data da defesa: 27-02-2004.
} 